\title{
The Role of T-Cash Public Relations in Building Brand Awareness Through @Tcash_Id Instagram Accounts
}

\author{
Rahajeng Puspitosari \\ rahajeng.puspitosari@budiluhur.ac.id \\ Universitas Budi Luhur
}

\begin{abstract}
The development of technology presents modern and all-digital innovation. The development of technology is present in various sectors, one of which is a payment instrument that is now not using cash payment instruments. One of the innovations of technological developments is the presence of Tcash. Tcash is an electronic money held by Telkomsel that has been registered and supervised by Bank Indonesiatherefore public relations Tcash utilizes @tcash_id Instagram account to build brand awareness. This study researchers use the post positivism paradigm. The research approach uses qualitative research which is a process of research and understanding based on methodology that investigates a social phenomenon and human problems. This study uses qualitative descriptive. Research uses the concept of public relations from Cutlip and Easts brand awareness concept. Based on the results of the research, TCashs public relations role in building brand awareness through @tcash_id Instagram account is the role of public relations as manager of @ tcash_id instagram accounts.
\end{abstract}

Keywords: Role of Public Relations, Brand Awareness, @Tcash_Id Instagram Account.

\section{Introduction}

Brand awareness or brand awareness is important. With brand awareness, a company can be better known and developed in the community. Brand awareness according to Aaker quoted in the book The Power of Brand by Freddy Rangkuti, brand awareness is the ability of a prospective buyer to recognize or recall that a brand is part of a particular product category[1]. Almost all companies are competing to gain brand awareness in the community. Starting from designing activities such as events to conducting promotional activities and publications.

Brand awareness becomes something that must be done by a company. One company that is building brand awareness is TCash. TCash is electronic money held by Telkomsel that has been registered and supervised by Bank Indonesia, has the same function as cash as a legal payment instrument, where the value is equal to the cash value deposited in TCash account. TCash, which was launched from 2007, has not received sympathy from the public. Almost all Indonesians know Telkomsel, but not many of them are not familiar with TCash.

From the lack of public interest and knowledge about TCash services, TCash makes Public Relations do various things such as using print and electronic media to use new media and social media. Instagram social media is something that is being loved in Indonesia, especially for teenagers. On Instagram we can see activities and pictures or photos shared by the owner of the account. TCash utilizes the Insagram's sophistication as a media campaign, publication of TCash brand awareness. Insagram is chosen because it is a social media that is being loved at this time. 
Instagram social media accounts at TCash are managed by a public relations officer. Public relations functions as the manager of Instagram social media accounts. Public relations manages @tcash_id as the only social media account of Telkomsel Cash. Public relations has a very important role in increasing TCash's consumer brand awareness. Public relations is a typical management function and supports coaching, maintenance of a shared path between the organization and the public, concerning communication, understanding, acceptance and cooperation activities, involving management in dealing with problems / problems, assisting management in follow and utilize changes effectively, act as an early warning system in anticipating the tendency of research use and healthy and ethical communication techniques as the main means[2].

\section{Methods}

This study used a qualitative approach and uses the concept of the role of public relations from Dozier \& Broom and , the other concepts used are the concept of Brand Awareness from David A. Aaker[3].

\section{Results}

\subsection{The Role of Public Relations Tcash}

A public relations must also be a communication facilitator, namely public relations acts as a communicator or mediator to help the management in terms of knowing what the public wants. Public relations also acts as a facilitator of the problem solving process and the last one is the public relations role as a communication technician.

As an expert advisor, TCash's public relations usually listens to complaints from public or TCash consumers. The use of social media and websites is used as a media for public complaints to TCash services. Usually the community sends a complaint to TCash through a website or social media that will be handled by TCash's public relations. If the problem cannot be resolved until the stage of Public Relations, the public relations contact the management or the party that is considered capable of solving the problem, then public relations will deliver the results to public TCash.

Besides that TCash Public Relations must also be able to convey or inform the interests of TCash companies to the public, and vice versa, TCash Public Relations must also be able to convey its public interest to the organization or management of TCash. For example there are additional features from TCash, Public Relations must be able to publish the information to the public both with print, electronic and media and features on the internet.

Furthermore TCash's public relations has a role as a facilitator of the problem solving process. Public relations has a role as a liaison between the organization and the public in solving problems. Almost every company or organization has experienced problems, as well as TCash. TCash experienced difficulties in taking cash and TCash services were not run at merchants appointed by TCash. As a result many publics are disappointed with the service. Seeing that TCash's public relations did not stay with him, the public relations immediately held a inspection and collected TCash technicians and immediately improved the TCash system, not forgetting 
that public relations also held a press release and mentioned apologies to all TCash consumers and promised to immediately repair the service.

As a communications technician, public relations must be able to be multifunctional, among others, as a press release maker and also as a journalist in the TCash company. Communication technicians mean that public relations must be multi-functional and multitalented.

\subsection{Building Brand Awareness Through Instagram Account @ Tcash_Id}

In this concept it is stated that there is a pyramid of brand awareness that is at the first level there is a Top of mind that is the brand that is first mentioned by consumers or which first appears in the minds of consumers. Furthermore, the brand recall is a spontaneous recall of the brand without help. Brand recognition is a minimal level of brand awareness where consumers are not aware of a brand even though recall has been done through assistance. And the last stage is unaware brand, the lowest level in the brand awareness pyramid where consumers are not aware of a brand even though they have recalled it through assistance.

The role of TCash's public relations in building brand awareness through @tcash_id instagram accounts is relatively new, this is because public relations is still looking for the right strategy to build TCash users' brand awareness with the segmentation of most of these young people. At first TCash was a product that was almost unknown to many people, Indonesians were very familiar with Telkomsel but not with other products like TCash. Another thing that makes TCash difficult to recognize by the people is the existence of TCash as a non-cash payment tool that is still rarely used by the Indonesian people at the beginning of its appearance.

TCash's public relations continues to improve rather to get better brand awareness in the eyes of the public. Until TCash held an event with the goal of "winning a lot". In the event held in 2017 involving many people and also TCash employees. The event uses publications such as Instagram and Facebook. Public interest is also quite good at this event. In this event, people were also introduced to the functions and uses of TCash. Especially in 2017 non-cash use in Indonesia, especially in Jakarta, has started a lot, such as the use of e-toll, payment through EDC machines and so on. At this stage the community begins to feel the TCash function which is felt to be beneficial for the economic sector. TCash is considered a simple non-cash alternative. People do not need to carry a lot of cash in their wallets simply by carrying a smartphone with the TCash application already in place. TCash filling is also easy and can be done anywhere. TCash does a lot of promos, this is what is commonly informed on social media, namely @tcash_id Instagram account. People are interested in the discount promos provided by TCash and in the end many people upload TCash applications.

Over time, TCash became one of the non-cash payment instruments favored by the public. Especially many people who are familiar with Telkomsel products. This can not be separated from the role of Public Relations in managing @tcash_id Instagram social media accounts. In the @tcash_id Instagram account a public relations has a role to manage the content of the Instagram account. With the social media instagram, the community especially TCash consumers can find out more about the latest features from TCash to the activities and events that will be held by TCash. The public can also ask questions in the comments column about TCash products as well as lots of prizes or quizzes given to the public via @tcash_id instagram account. Currently the number of followers of TCash Instagram accounts reaches 503 thousand users. And almost every day content uploads.

TCash eventually became a brand that was well known by the public. The TCash logo used on community smartphones makes TCash a highly sought-after non-cash payment application. 
With TCash, Telkomsel providers were also positively affected. Telkomsel is one of the largest providers in Indonesia.

\section{Conclusion}

The conclusion of this research is TCash's public relations using @tcash_id Instagram account as a publication tool to build brand awareness. Currently TCash has succeeded in becoming a non-cash payment brand favored by the public. Public relations has the task of managing @tcash_id Instagram accounts and making them into Instagram accounts that are well known to the public with more than 500 thousand followers. And strategy to build the brand awareness is succesfull.

\section{References}

[1] M. Hitchcock, “"Cashless: Bible Prophecy, Economic Chaos, \& The Future Financial Order," 2009.

[2] Sopian, Public Relations Writing: Konsep, Teori, Praktik. Jakarta: Gramedia.

[3] D. Aaker, "Manajemen Ekuitas Merek 'Memanfaatkan Nilai dari Suatu Merek," Spectrum. 